\title{
ДО ПИТАННЯ ЮРИДИЧНОЇ СУТНОСТІ КРИМІНАЛЬНОЇ ВІДПОВІДАЛЬНОСТІ ВІЙСЬКОВОї СЛУЖБОВОї ОСОБИ
}

\section{ON THE ISSUE OF THE LEGAL ESSENCE OF CRIMINAL LIABILITY OF A MILITARY OFFICER}

\begin{abstract}
у статті проаналізовано сучасні концепчії національного законодавства стосовно тлумачення поняття «військова службова особа». З'ясовано, що проблеми визначення правового статусу зазначеної особи в розумінні суб'єкта - посадової чи службової особи малорозроблені. Встановлено, що тлумачення поняття «посадова особа» ми не знаходимо в нормах кримінального законодавства, проте вживається термін «службова особа» (стаття 18 Кримінального кодексу України).
\end{abstract}

Досліджено доктринальні концепції «службова особа - посадова особа - військова службова особа - військова влада» та прове дено аналіз національного законодавства із визначеної проблематики.

Встановлено наявність правової прогалини у визначенні поняття «посадова особа». З'ясовано, що під час квалісрікації фрорм «службова особа» та «посадова особа» науковці беруть за критерій розподілу різні чинники. Наприклад, дослідники взяли за основу розуміння сутності управління та виокремили юрисдикційну форму діяльності службовоі особи, відмежували ії від діяльності посадово особи. Як наслідок, у межах відповідної форми управління науковці зазначають, що особа вибирає той характер поведінки, предмет но-об'єктна специфріка якого передбачає особливий організаційно-правовий механізм.

Запропоновано за дотримання вищеописано кваліфікації понять убачати чіткий взаємозв'язок між службовою особою та посадовою особою, із застереженням, що кожна посадова особа є службовою особою, натомість не кожна службова особа наділена фрункціями управління, отже, не є посадовою особою. За результатами системного аналізу чинного законодавства обгрунтовано, що військове керівничтво із чітко визначеною ієрархічною структурою за своєю правовою природою можна ототожнити з військовою владою, одиничним суб'єктом є військова службова особа, проте приналежність військової службової особи до військової влади не $\epsilon$ безумовною.

Запропоновано подальші наукові пошуки присвятити дослідженню аргументів на користь перегляду положень кримінального законодавства стосовно видів криміналь ної відповідальності за колом суб'єктів відповідно до критеріїв їхньої приналежност (військова службова особа, посадова особа, військова влада) у зв'язку з різними їхніми правовими статусами.

Ключові слова: особа, військовослужбовець, посадова особа, військова влада, військове управління.

The article analyses modern concepts of national legislation regarding the interpretation of "a military officer". It was found that the problems of determining their legal status in the interpretation of the subject - official or officer - are poorly developed. It is established that we do not find the interpretation of "an official" in the provisions of criminal law, but the term "officer" is used (Article 18 of the Criminal Code of Ukraine).

The doctrinal concepts of "officer - official - military officer - military authority" are studied, and the national legislation on the certain problems is analysed.

The legal gap in the definition of an official is established. It was found that when qualifying the forms of an official and an officer, scholars take different factors as a distribution criterion. For example, taking interpretation of the essence of management as a basis, researchers identified the jurisdictional form of officer's activity, distinguishing it from the official's activities. As a result, within the appropriate form of management, scholars note that a person chooses the nature of behaviour, the subject-object specifics of which has a special organizational and legal mechanism

It is suggested that, following the above qualifications, we see a clear relationship between an officer and an official, with the proviso that every official is an officer, but not every officer is endowed with management functions and is therefore not an official.

Based on a system analysis of current legislation, we substantiated that military leaders with a clearly determined hierarchical structure by its legal nature can be identified with military authority, the sole subject of which is a military officer, but military officer's affiliation with the military authority is not unconditional.

It is proposed to direct further research to the study of arguments in favour of revising the provisions of criminal law on the types of criminal liability for a range of subjects in accordance with the criteria of their affiliation (military officer, official, military authority) due to their different legal status.

Key words: officer, serviceman, official, military authority, military administration.

\section{Постановка проблеми в загаль-} ному вигляді. у 2001 р. ухвалений новий Кримінальний кодекс (далі - КК) України. Відтоді станом на 2020 р. ухвалені більше 180 законів, якими внесено зміни та доповнення до Кодексу. Однак за такої динаміки якість законів не така, як мала б бути. На думку науковців, «у доктрині кримінального права досі не сформульовано основоположного - принципів кримінального права та концепції його розвитку» [1, с. 66]. Зокрема, зазначено недосконалість тлумачення норм, що формують галузь, що є визначальним для з'ясування законного й обґрунтованого її застосування, та наявність невідповідності приписів КК України положенням конституційного права.

Так, відповідно до ст. 19 Конституції України [2], посадові особи зобов'язані діяти лише на 
підставі, у межах повноважень та у спосіб, що передбачені Основним законом та законами України. Хоча тлумачення поняття «посадова особа» ми не знаходимо в нормах кримінального законодавства, проте вживається термін «службова особа» (ст. 18 КК України) [3]. Певна річ, така прогалина $€$ наслідком поспішного ухвалення законів, нехтування принципами права, «без чіткої концептуальної моделі кримінального законодавства» [1, с. 66]. Отже, можемо констатувати, що структура правового механізму визначення суб'єкта кримінального правопорушення потребує вдосконалення. У нинішній конструкції українського кримінального права цей інститут дещо відрізняється за змістом від юридичної конструкцій Основного закону. Звернення до літератури із кримінального права дає змогу з'ясувати, що науковці суб'єктом злочину вважають «лише фізичну особу» [4, с. 139], оцінюють останню за критеріями осудності, неосудності чи обмеженої осудності. Однак усі ці кваліфікуючі ознаки пов'язані, зокрема, і зі службовими особами. Отже, постають закономірні запитання:

1) чи вважається військова службова особа службовою особою в розумінні кримінального законодавства?

2) чи можна вважати військову службову особу посадовою особою?

Теоретично та практично важливе обговорення визначеного обсягу правової відповідальності військових службових осіб, установленого нормами КК України. Це недбале ставлення до військової служби (ст. 425), бездіяльність військової влади (ст. 426), перевищення військовою службовою особою влади чи службових повноважень (ст. 426-1). Особливе місце серед злочинів, які вчиняються військовими службовими особами, посідає бездіяльність військовослужбовців, зокрема керівного складу військового управління. Такі факти мають дестабілізуючий характер та підпадають під ознаки ст. 426 КК України, за своєю суттю кваліфікуються як злочин, скоєний групою осіб із метою порушення мирної ситуації в окремому регіоні або країні, та не тільки посягають на нормальну роботу певної військової установи, організації, а охоплюють саме існування всієї військової організації держави.

На нашу думку, сучасний стан розвитку держави та світу загалом потребує докорінного переосмислення правових положень кримінального законодавства щодо розуміння доктринальної концепції «службова особа посадова особа - військова службова особа військова влада».

Аналіз останніх досліджень і публікацій. У національній кримінально-правовій науці на проблему суб'єктів кримінальної відповідальності звертали увагу В.В. Богуцький, Є.І. Григоренко, С.М. Мельник, С.Ю. Поляков, В.В. Стасиша, В.Я. Тацій, Н. Хома й інші.

Виділення не вирішених раніше частин загальної проблеми. Вивчення спеціальної літератури доводить, що спеціальні дослідження ст. 426 КК України нині малозроблені, а проблеми караності військових службових осіб та визначення їхнього правового статусу в розумінні суб'єкта - посадової чи службової особи розглядались в обмеженому обсязі.

Метою статті є дослідження суті та розуміння доктринальної концепції «службова особа - посадова особа - військова службова особа - військова влада», аналіз національного законодавства з визначеної проблематики.

Виклад основного матеріалу. У контексті дослідження правового становища військової службової особи варто розпочати 3 аналізу визначення понять «посадова особа» та «службова особа». Тлумачення терміна «службова особа» ми знаходимо в положеннях КК України. Згідно із ч. 3 ст. 18 КК України, службовими особами визначаються «особи, які постійно, тимчасово чи за спеціальним повноваженням здійснюють функції представників влади чи місцевого самоврядування $\langle\ldots\rangle$ пов'язані 3 виконанням організаційно-розпорядчих чи адміністративно-господарських функцій" [3]. Аналогічні тлумачення поняття «службова особа» містяться у примітці 1 ст. 364 КК України.

Вдаючись до аналізу пропонованих представниками науки думок щодо визначення терміна «службова особа», видається доцільним зауваження, що «термін «службова особа» $€$ більш широким за своїм змістом і визначається характером службової діяльності особи залежно від об'єкта й сфери владних повноважень <...> управлінських функцій щодо підлеглих <...> тобто можливості здійснювати внутрішнє управління (адміністрування) <..> носіями є посадові особи <...> наділені функціональною владою, які забезпечують практичне здійснення службових завдань і функцій управління <..> Таку групу службовців становлять службові особи» [5, с. 142].

Науковці для кваліфікації форм «службова особа» та «посадова особа» беруть за критерій розподілу різні чинники. Наприклад, взявши за основу розуміння сутності управління, дослідники виокремили юрисдикційну форму діяльності службової особи, відмежували її від діяльності посадової особи. Як наслідок, у межах відповідної форми управління особа вибирає той характер поведінки, 
предметно-об'єкта специфіка якого передбачає особливий організаційно-правовий механізм. Дотримуємося вищеописаної кваліфікації понять і вбачаємо чіткий взаємозв'язок між службовою особою та посадовою особою, з одного боку, кожна посадова особа є службовою особою, натомість не кожна службова особа наділена функціями управління, отже, не $є$ посадовою особою.

Уважаємо, що в розмежуванні понять «службова особа» та «посадова особа» необхідно виходити з того, що контроль $є$ діяльністю уповноважених суб'єктів - посадових осіб, визначається особливим статусом суб'єктів їх здійснення, отже, є особливим видом публічного адміністрування, спрямованим «на вчинення дій із виявлення та припинення правопорушень із боку підконтрольного суб'єкта» [6, c. 122].

Окремо звернемо увагу на визначення поняття «військова службова особа». До ключових критеріїв правової характеристики військової службової особи варто віднести її приналежність до відокремленої системи правових норм.

Розуміння категорії «військова служба» ми знаходимо в Законі України «Про військовий обов'язок та військову службу». Так, відповідно до ст. 2 Закону, «військова служба є державною службою особливого характеру, яка полягає у професійній діяльності <...> громадян України, пов'язаній з обороною України, її незалежності та територіальної цілісності» [7]. Отже, військова служба є специфічним видом державної служби, особи, які її проходять, уважаються військовослужбовцями. Такий термін уживається у спеціальному законодавстві.

У примітці 1 ст. 425 КК України законодавець уже вживає поняття «військова службова особа», до таких відносить «військових начальників, а також інших військовослужбовців, які обіймають постійно чи тимчасово посади, пов'язані з виконанням організаційно-розпорядчих або адміністративно-господарських обов'язків, або виконують такі обов'язки за спеціальним дорученням уповноваженого командування» [3]. У продовження дослідження правового статусу військової службової особи додатково проаналізовано закони України «Про Збройні Сили України» та «Про оборону України». Інакше кажучи, у спеціальному законодавстві, яке регулює питання військової служби, уживається термін «військовослужбовці», а не «військова службова особа». Отже, можемо стверджувати, хоча поняття «військовослужбовець» та «військова службова особа» структурно різні, проте тотожні за своїм змістом.
На сучасному етапі можемо виокремити декілька категорій військових службових осіб (військовослужбовці), які за своїм статусом розподіляються на керівний та підпорядкований склад. Зокрема, таке твердження випливає зі змісту ч. 12 ст. 6 Закону України «Про військовий обов'язок та військову службу», відповідно до якої «військовими посадовими особами визначаються військовослужбовці, які обіймають штатні посади, пов'язані з виконанням організаційно-розпорядчих чи адміністративно-господарських обов'язків, або які спеціально уповноважені на виконання таких обов'язків згідно із законодавством» [7].

Додатково звернемо увагу на судову практику. Зазвичай судова практика, яка $є$ різновидом правозастосовної практики, сприяє подоланню недоліків нормативно-правових актів та формуванню правових висновків про правильне застосування норм матеріального права.

Так, колегія суддів другої судової палати Касаційного кримінального суду Верховного Суду (постанова від 17 травня 2018 р. у справі № 340/545/15-к) дійшла такого висновку: «Визнаючи особу військовою службовою особою, представником військової влади, суди першої та апеляційної інстанції не врахували нормативне визначення військової службової особи, яке згадок про представників влади не містить <...> системний аналіз чинного законодавства свідчить, що закон виокремлює 3 групи військових службових осіб: 1) військові начальники; 2) військовослужбовці, що виконують організаційно-розпорядчі обов'язки; 3) військовослужбовці, що виконують адміністративно-господарські обов'язки. Перші із цих осіб не є представниками влади. Що ж стосується інших категорій військових службових осіб, то за своїм змістом організаційно-розпорядчі та адміністративно-господарські обов'язки лише прив'язуються до військової сфери <...>» [10].

Також Суд приходить до переконання, що служба у правоохоронних органах та зайняття військової посади, з якою особа набуває статусу військовослужбовця, або військової службової особи, не є прямим свідченням здійснення організаційно-розпорядчих або адміністративно-господарських функцій особою.

Отже, підсумовуючи зазначене, можна констатувати, що військова службова особа за своїми функціями може здійснювати організаційно-розпорядчі й адміністративно-господарські функції, проте вона залишається лише службовою особою. Натомість, зважаючи на правову прогалину законодавства щодо визначення поняття «посадова особа», 
ми не можемо однозначно стверджувати, що військова службова особа $є$ водночас посадовою особою. Судова практика не усунула натепер такий недолік нормативно-правового акта, відповідно моделювання кримінальної відповідальності військової службової особи без розуміння критеріїв її приналежності до посадових осіб ілюструє наявність правового упущення, що не сприяє належному розумінню сутності поняття «військова службова особа» у диференціації посадових осіб. Отже, уважаємо, що вжите в положеннях Основного закону поняття «посадова особа» натепер не має відповідного нормативного закріплення, як наслідок, відсутній необхідний для їх реалізації правовий механізм.

Аналіз правової конструкції «засудження до відповідальності за бездіяльність військової службової особи» крізь призму застосування ст. 426 КК України свідчить, що суб'єктом відповідальності є військова службова особа, однак, оскільки військова службова особа - будь-яка особа, яка $є$ військовослужбовцем, то дана норма за своїм змістом застосовна до невизначеного кола осіб, які проходять військову службу. Проте таке твердження є хибним, зважаючи на вищезгадану судову практику. Навіть більше, як свідчать наявні в літературі фахові тлумачення, зміст понять «військова службова особа» та «посадова особа» потребує додаткових пояснень та досліджень.

3 метою надання повного й обґрунтованого термінологічного трактування словосполучення «військова службова особа» звернемо увагу на ст. 18 КК України. У ч. 3 ст. 18 КК України зазначено, що «службовими особами $€$ особи, які постійно, тимчасово чи за спеціальним повноваженням здійснюють функції представників влади чи місцевого самоврядування, а також постійно чи тимчасово обіймають в органах державної влади, органах місцевого самоврядування, на підприємствах, в установах чи організаціях посади, пов'язані з виконанням організаційно-розпорядчих чи адміністративно-господарських функцій, або виконують такі функції за спеціальним повноваженням, яким особа наділяється повноважним органом державної влади, органом місцевого самоврядування, центральним органом державного управління із спеціальним статусом, повноважним органом чи повноважною службовою особою підприємства, установи, організації, судом або законом» [3]. Аналогічне тлумачення можна знайти в абз. 1 примітки 1 ст. 364 КК України.

У результаті проведеного аналізу відповідних законодавчих норм убачається своєрідна суперечливість між нормами матеріального права. Зокрема, питання співвідношення за змістом та обсягом дефініцій термінів «військова влада»» та військові службові особи» залишається невизначеним.

Отже, диспозиція норми ст. 426 КК України, яка містить підстави стосовно відповідальності за бездіяльність військової влади, за критерієм суб'єкта злочину є недосконалою та потребує уточнення і доопрацювання. До недоліків вказаної норми можна віднести відсутність у КК України визначення термінів «військова службова особа», «посадова особа» та «військова влада», що обмежує оціночне розуміння суб'єкта правопорушення за критерієм його приналежності до відповідної категорії осіб. Проте тавтологічне вживання щодо поняття «військова службова особа» терміна «службова особа» не позбавлене відповідного правового сенсу, проте в конструкції норми ст. 426 КК України оцінюеться нами критично, оскільки останньою регулюється відповідальність військової влади. Доповнюючи кримінологічне тлумачення вказаної норми, доречно зазначити, що в судовій практиці зауважене не віднесення на законодавчому рівні військової службової особи до представників військової влади.

Отже, важливим структурним елементом у застосуванні ст. 426 КК України є визначення чітких критеріїв військових службових осіб крізь призму доктринального розуміння поняття «посадова особа», приналежності таких осіб до військової влади. Заради цього доречно усунути прогалину в термінологічних положеннях кримінального законодавства 3 метою однозначності правозастосовної практики, водночас варто врахувати співвідношення ст. ст. 18, 364 та примітки 1 ст. 425 КК України стосовно визначення функціонального переліку військових службових осіб та їхніх обов'язків.

Водночас залишення усунення недоліків законодавства щодо тлумачення поняття «військова влада» безпосередньо судовій практиці не $є$ доцільним, оскільки сутність законодавця полягає у створенні якісних нормативно-правових актів, натомість правозастосовна практика спрямована на формування єдиного механізму застосування приписів, а не усунення прогалин.

Щодо питання військової влади важливо зазначити таке. Згідно з п. 17 ч. 1 ст. 106 Конституції України та ст. 7 Закону України «Про Збройні Сили України», Президент України є Верховним головнокомандувачем Збройних сил України.

Водночас до керівництва Збройними силами України законодавець відносить Міністра оборони України, який $€$ «голов- 
нокомандувач Збройних Сил України <..> найвищою військовою посадовою особою у Збройних Силах України» [8], «командувачі видів, окремих родів військ (сил) Збройних Сил України <..>> командувачі (керівники) інших військових формувань» [8]. Особливості повноважень керівництва Збройними силами України полягають у військово-політичному, адміністративному та безпосередньому їх керівництві.

Отже, військове керівництво Збройними силами України забезпечує реалізацію державної політики у сфері оборони, її функціонування та розвиток, з відповідними особливостями, притаманними військовій службі. Законодавець окреслює і перелік суб'єктів керівного складу Збройних сил України, виокремлює три інституції, які наділені різною повнотою військової влади, а саме: «військово-політичне керівництво Збройними Силами України», «адміністративне керівництво Збройними Силами України», «безпосереднє військове керівництво Збройними Силами України» [8]. Відповідно до абз. 16 ст. 1 Закону «Про оборону України», до складу військового командування «відносяться - Генеральний штаб Збройних Сил України, Об'єднаний оперативний штаб Збройних Сил України, командування видів Збройних Сил України, командування Сил спеціальних операцій Збройних Сил України, командування десантно-штурмових військ Збройних Сил України, управління оперативних командувань, командування з'єднань, військових частин Збройних Сил України та інших утворених відповідно до законів України військових формувань» [9]. Відповідно до ч. ч. 4 та 5 ст. 8 згаданого Закону, начальник Генерального штабу - Головнокомандувач Збройних сил України здійснює безпосереднє військове керівництво останніми.

Додатково термін «військово-політичне керівництво» надано законодавцем в абз. 2 ч. 1 ст. 6 Закону «Про Національну гвардію України», де зазначено, що «<...> військово-політичне керівництво Національною гвардією України - це діяльність, спрямована на забезпечення реалізації державної політики у сфері діяльності Національної гвардії України, політичних та стратегічних цілей, принципів і напрямів її розвитку <...>» [11].

Зі змісту Закону України «Про правовий режим воєнного стану» [12] військове командування вживається у значенні, наведеному залежно від правового режиму, тобто, окрім уже попередньо визначеного кола «військового командування (ст. 3) додаються військові адміністрації (ч. 1 ст. 3 та ст. 4)» [12].
Відповідно до ст. 3 Закону України «Про військово-цивільні адміністрації», «військово-цивільні адміністрації - це тимчасові державні органи у селах, селищах, містах, районах та областях, що діють у складі Антитерористичного центру при Службі безпеки України (у разі їх утворення для виконання повноважень відповідних органів у районі проведення антитерористичної операції) або у складі Об'єднаного оперативного штабу Збройних Сил України» [13].

За результатами системного аналізу чинного законодавства можна підсумувати, що військове керівництво із чітко визначеною ієрархічною структурою за своєю правовою природою можна ототожнити з військовою владою, одиничним суб'єктом є військова службова особа, проте приналежність військової службової особи до військової влади не $є$ безумовною. Водночас, якщо розглядати військову владу з позиції відповідного органу державної влади, необхідне переосмислення її побудови (конструкції) та змістовності повноважень, якими наділений відповідний управлінський орган для розуміння місця військової службової особи в даній системі формувань.

Висновки. Отже, відсутність у національному законодавстві визначення щодо безумовної належності військової службової особи до військової влади, диференціація критеріїв відмінності військової службової особи від посадової особи дають право на твердження, що за сукупними ознаками військовослужбовці не є суб'єктом військової влади, проте є первинною ланкою військової влади як суб'єкта державного управління. Водночас осіб, наділених повноваженнями публічної влади, можна віднести до посадових осіб військової влади. Отже, подальші наукові пошуки варто присвятити дослідженню аргументів на користь перегляду положень кримінального законодавства стосовно аналізу видів кримінальної відповідальності за суб'єктом відповідно до критеріїв їх приналежності (військова службова особа, посадова особа, військова влада) у зв'язку з різними їхніми правовими статусами.

Водночас приходимо до переконання, що терміни «військова службова особа» та «військова влада» не є автентичними, як наслідок, застосування норм кримінального права, що визначають відповідальність військової службової особи, неможливе до військової влади. Нині можна говорити про наявність правової прогалини у кримінальному праві щодо суб'єкта відповідальності - військової влади. Отже, натепер положення кримінального законодавства демонструють відставання від 
викликів та тенденцій сучасного світу, як наслідок, потребують перегляду та доопрацювання 3 метою усунення правової невизначеності окремих положень чинних нормативно-правових актів із питань урегулювання порушеної проблематики.

\section{ЛІТЕРАТУРА:}

1. Тертишник В.В., Сачко О.В., Кошовий О.Г. Принципи права в інтегрованій доктрині вдосконалення кримінального законодавства. Актуальні проблеми вітчизняної юриспруденції. 2018. Вип. 3. С. $66-70$.

2. Конституція України від 28 червня 1996 р. URL: https://zakon.rada.gov.ua/laws/show/254\%D0\%BA/96D0\%B2\%D1\%80\#Text.

3. Кримінальний кодекс України від 5 квітня 2001 p. № 2341-III. URL: https://zakon.rada.gov.ua/ laws/show/2341-14\#Text (дата звернення: 30.09.2020).

4. Стасиша В.В., Тацій В.Я. Кримінальне право України. Загальна частина. Харків : Право, 2010. $456 \mathrm{c}$.

5. СамофраловЛ.П.,СамофраловО.Л.Особливості розуміння понять «посадова особа», «службова особа», «представник влади» та їх значення у правовому регулюванні пенітенціарних правовідносин. Науковий вісник Національної академії внутрішніх справ. Київ, 2015. № 4 (97). С. 136-148.

6. Запотоцька О.В. Поняття та особливості контролю як засобу публічного адміністрування у сфрері безпечності та якості харчової продукції. Актуальні проблеми вітчизняної юриспруденції. Дніпро, 2018. № 3. С. 120-124.

7. Про військовий обов'язок та військову службу : Закон України від 25 березня 1992 р. № 2232-XII. URL: https://zakon.rada.gov.ua/laws/show/2232-12\#Text (дата звернення: 30.09.2020).

8. Про Збройні Сили України : Закон України від 6 грудня 1991 р.№ 1934-XII. URL: https://zakon. rada.gov.ua/laws/show/1934-12\#Text (дата звернення: 30.09.2020).

9. Про оборону України : Закон України від 6 грудня 1991 р. № 1932-XII. URL: https://zakon.rada. gov.ua/laws/show/1932-12\#Text (дата звернення: 30.09.2020)

10. Постанова ККС ВП від 17 травня 2018 р. у справі № 340/545/15-к. URL: https://protocol. ua/ru/postanova_kks_vp_vid_17_05_2018_roku_u_ spravi $340545 \overline{15}$ k/ (дата звернення: 30.09.2020).

11. Про Національну гвардію України : Закон України від 13 березня 2014 р. № 876-VII. URL: https://zakon.rada.gov.ua/laws/show/876-18\#Text (дата звернення: 30.09.2020).

12. Про правовий режим воєнного стану : Закон України від 12 травня 2015 р. № 389-VIII. URL: https:// zakon.rada.gov.ua/laws/show/389-19\#Text (дата звернення: 30.09.2020).

13. Про військово-цивільні адміністрації : Закон України від 3 лютого 2015 р. № 141-VIII. URL: https:// zakon.rada.gov.ua/laws/show/141-19\#Техt (дата звернення: 30.09.2020). 